\title{
Eugenics, Prejudice, and Psychological Research
}

\section{Elliot Turiel}

University of California, Berkeley, CA, USA
What do we want Haitians here for? Why do we want all these people from Africa here? Why do we want all these people from shithole countries? We should have people from countries like Norway.

Donald J. Trump at a January 11, 2018 meeting on immigration in the White House

One idea he insistently taught was that black people have been kept in oppression and deprivation by a poisonous fog of lies that depicted them as inferior, born deficient, and deservedly doomed to servitude to the grave... So long as the lie was believed the brutality and criminality of conduct toward the Negro was easy for the conscience to bear. The twisted logic ran: if the black man was inferior he was not oppressed - his place in society was appropriate to his meager talent and intellect.

Martin Luther King Jr., speech honoring W. E. B. Du Bois, New York City, February 23, 1968

The great evil of American slavery wasn't the involuntary servitude; it was the fiction that black people aren't as good as white people, and aren't the equals of white people, and are less evolved, less human, less capable, less worthy, less deserving than white people ... So, for me, you can't understand these present-day issues without understanding the persistent refusal to view black people as equals.

Bryan Stevenson, Executive Director of the Equal Justice Initiative, New Yorker, June 1, 2020

Because, you know, for centuries now, so much of the West, including America, has been infected, if I can use the word, by a pandemic of hatred, a pandemic of suspicion that rests on the fundamental lie that black people are inferior and white people are superior. That's the lie that permeates our society.

Stephen L. Carter, William Nelson Cromwell Professor of Law, Yale University, National Public Radio, May 30, 2020

karger@karger.com

(c) 2020 S. Karger AG, Basel

www.karger.com/hde

Karger"
In these comments, Donald Trump, Martin Luther King Jr., Bryan Stevenson, and Stephen L. Carter are talking about a central element of the concepts underlying eugenics. King, Stevenson, and Carter, of course, are highly critical of what they describe as a fundamental lie. They assert that these lies permeate America. In contrast, Donald Trump, who was elected to the highest office in America, indicates his belief that Black people are inferior to Whites, that Black people are not equal to superiors from Nordic countries. Trump is often depicted as racist, and many of his assertions and actions support that depiction. Racism underlies his leading role in birther movement claims that President Barack Obama was born in Africa, as well as his repeated denigration of "low IQ" and "dumbest" individuals (mostly African-Americans). Trump appealed to racism during the 2020 presidential campaign after Kamala Harris (a woman of color) was named as Joe Biden's Vice-Presidential running mate. Trump tweeted,

"The 'suburban housewife' will be voting for me. They want safety $\&$ are thrilled that I ended the long running program where low income housing would invade their neighborhood. Biden would reinstall it, in a bigger form, with Corey Booker in charge!" (Trump, 2020)

Corey Booker, who had never been mentioned for such a position, is an African-American Senator from New Jersey.

The most invidious underlying concept for Trump's racism is eugenics. Although he may not know the term, 
he certainly appears to hold a deep belief in the core of eugenics: that hereditary differences exist between groups of people, especially in levels of intelligence. Eugenics posits, further, that selective breeding should result in desirable characteristics, with breeding of undesirable characteristics discouraged. Immigration policies should favor people from Nordic and other Northern European countries while banning or severely restricting those from places like Africa. ${ }^{1}$

\section{The Growth of Eugenics}

In Du Bois' time, the early twentieth century, eugenics was by no means a fringe idea. Tenets of eugenics were promoted widely. There were critics, but the movement was very influential. Eugenics emerged in the late 1800 s through the biological work of Francis Galton, an Englishman and cousin of Charles Darwin (Cohen, 2016; Leonard, 2016). In the United States, many presidents of universities, researchers, and scholars promoted eugenics - including at Harvard, Yale, Cornell, Columbia, Stanford, and many more universities (Cohen, 2016). University researchers in economics, biology, primatology, botany, zoology, anthropology, and psychology incorporated eugenics in their writings and research. During the twentieth century's first three decades:

"Hundreds and probably thousands of scholars and scientists, including the world's most eminent geneticists, proudly proclaimed to be eugenicists. They raised millions to fund eugenic laboratories and founded a passel of scholarly journals dedicated to the study of eugenics and eugenic policy. They convinced governments to regulate marriage, reproduction, immigration, and labor in the name of eugenics." (Leonard, 2016, p. 190)

One of the most influential institutions studying and promoting eugenics was the Cold Spring Harbor Laboratory, with a Eugenics Record Office that collected and analyzed family genetic and trait history among Americans. Additional institutions and journals were devoted to eugenics research. ${ }^{2}$

Eugenicists lobbied for legislation restricting immigration of people with "deficient heredity," arguing that Northern Europeans, especially from countries like Norway, were innately superior to those from non-Northern European countries (e.g., Italians) as well as Jews. Legislation, most notably the Immigration Act of 1924, allowed for more immigrants from Northern Europe, placing severe restrictions on immigrants from Southern and Eastern Europe.
Medical professionals and heads of medical institutions also supported eugenics, and some took steps to implement supportive policies. Physicians implemented recommendations of the American Academy of Medicine for the "elimination" of those deemed unfit by heredity (Cohen, 2016). The main methods within the United States prevented reproduction by the unfit through institutionalization and forced sterilization. Many states adopted laws allowing the institutionalization and/or sterilization of the unfit during their reproductive years.

The state of Virginia maneuvered a test case up to the United States Supreme Court, confident the Court would uphold sterilization. Its 1927 decision, Buck v. Bell, proved them right. Carrie Buck had been sent to a "Colony for Epileptics and Feeble-Minded" after giving birth to a child. Her mother had also been institutionalized. The Buck case upheld Virginia's sterilization law. As Oliver Wendell Holmes put it, writing the eight to one decision, "experience has shown that heredity plays an important part in the transmission of insanity, imbecility, \&c." and famously, "Three generations of imbeciles are enough" (Supreme Court of United States, 1927).

\section{Psychologists Enlarge Testing}

Justice Holmes' reference to three generations involved Carrie Buck, her mother, and Carrie's infant daughter. They were categorized as "imbeciles" based upon results of the Binet-Simon intelligence test, administered at the Virginia institution. Many psychologists rendered the Binet-Simon test as a measure of innate intelligence. Its scores delineated a hierarchy ranging from "idiots" (mental age below a normal 3-year-old), to "imbeciles" (mental age between 3 and 7 years), and "morons" (mental age between 8 and 12 years). Supposedly, these categories reflected not only low levels of intelligence but also causes

\footnotetext{
1 Interestingly, Trump stated at a campaign rally in Minnesota (a state with many descendants from Scandinavia), "You have good genes, you know that, right? A lot of it is about genes, isn't it? Don't you believe? The racehorse theory. You think we are so different? You have good genes in Minnesota." Racehorse theory refers to breeding of horses and has been applied to humans. Indeed, eugenics encompasses Trump's policies on immigration, fueled by the anti-immigration hard-liner Stephen Miller who, no coincidence, remained one of Trump's few original advisors. A view of Miller as a white supremacist is supported by a trove of his emails uncovered by the Southern Poverty Law Center. Miller's views also underlie Trump's policy of separating children from parents seeking asylum at the southern border.

2 Among the prominent people endorsing eugenics were US presidents Theodore Roosevelt, Woodrow Wilson, Warren G. Harding, and Calvin Coolidge. From the field of literature those often mentioned include T.S. Eliot, D.H. Lawrence, and Jack London.
} 
of moral deficiencies, such as delinquency, crime, alcoholism, and prostitution. Many sterilizations occurred before the 1927 Supreme Court decision, but many more thousands of people were sterilized in its aftermath.

Binet had not intended his test as a measure to classify children in these ways (Gould, 1981). However, several American psychologists attempted to revise and standardize Binet's measures - while using the categories of idiot, imbecile, and moron. In the process, they reified the notion that intelligence is a unitary inherited trait that could be assessed in one general score - an intelligence quotient (IQ). The American psychologists who were most influential in connecting eugenics with IQ were Lewis Terman of Stanford and Robert Yerkes of Harvard. ${ }^{3}$ Terman created the Stanford-Binet scale, mainly measuring, he claimed, innately determined intelligence - which, in turn, reflected racial differences, social class differences, and the usual eugenic moral features (see Cohen, 2016 and Gould, 1981 for discussions of Terman's positions on matters like delinquency and crime). Yerkes, who solidified the widespread use of intelligence tests by administering them to nearly two million army recruits during World War I, also regarded intelligence test scores as a measure of native intellectual ability.

The propositions put forth by Terman and Yerkes, that racial and social class differences in IQ scores reflected differences in innate intelligence, were consistent with predominant views in the eugenics movement. Among well-known volumes on eugenics that emphasized racial difference, two best sellers were particularly influential (see Frazier, 2019). In The Passing of the Great Race, Madison Grant maintained that Northern Europeans were innately superior to Blacks and Jews and other non-Nordics. The Rising Tide of Color Against White World Supremacy by Lothrop Stoddard (a journalist and political scientist) depicted the inferiority of people of color, warning of the potential demise of the superior White race if preventive steps were not taken. ${ }^{4}$

Even as laws supported segregation of Blacks and Whites in, for instance, education and housing, arguments counter to eugenicists' ideas did arise. Eventually, the American eugenics movement lost some of its momentum in light of Nazi atrocities during World War II in the name of eugenics. ${ }^{5}$ Since World War II, a number of psychologists have disputed the hereditary and unitary conceptions of intelligence. Nevertheless, others continued to use IQ test measures to claim that innate differences exist between White and Black people, as well as between social classes. An example is Jensen's (1969) assertion that approximately $80 \%$ of measured intelligence is due to heredity and that lower scores by African-Americans compared to Whites reflect genetic differences (Herrnstein, 1971, made similar claims regarding social class differences; see also Herrnstein and Murray, 1994). Jensen asserted, furthermore, that interventions, like Head Start, designed to provide enhanced early education to preschoolers, would be ineffective because most of intelligence is biologically determined and thus unalterable.

Aversion to Nazi practices did not eliminate eugenic sterilization. Forced sterilization continued in the United States beyond the civil rights movement of the 1960s, and though the Civil Rights Act of 1965 outlawed segregation, of course, racial prejudice and discrimination continue.

\section{Positive Trends in Psychology Post World War II}

After World War II, psychology focused increasingly on efforts to research racial and ethnic prejudice and discrimination - as well as ways to reduce prejudice. Two comprehensive volumes from that period are The $A u$ thoritarian Personality (1950) by Adorno and colleagues and The Nature of Prejudice (1954/1958) by Gordon Allport. The Authoritarian Personality research was motivated in part by the need to better understand the virulent anti-Semitism of the Holocaust. However, the research addressed more broadly ethnocentrism - a concept more general than prejudice. The conclusion derived from this research was that high and low levels of ethnocentrism (and prejudice) are rooted in deep-lying personality traits and psychological needs. From the authors' psychodynamic perspective, deep-rooted personality traits, de-

\footnotetext{
3 Another influential psychologist was Charles Spearman of the University College, London, who developed factor analysis as a presumably more accurate way to assess IQ.

4 For an interesting recounting of public debates between Stoddard and Du Bois see Frazier (2019).

While some American proponents of eugenics admired Nazi Germany (Wilkerson, 2020), Hitler and other high Nazi officials admired writings, court decisions, and legislation supported by American eugenicists. Features of US eugenic policies were incorporated into the Nuremberg Laws of 1935 requiring that all citizens have German blood, decreeing that Jews were of a different race and thus stripped of citizenship and other rights. In this context, I should mention that as a child I had direct experiences with German Nazis. I was born during World War II into a Sephardic Jewish community on the Greek island of Rhodes, but at the time an Italian possession. In 1943 Germany ousted the Italians and took over the island. In July of 1944 they deported about 1,700 Jews from Rhodes to the concentration camp in Auschwitz. My family and 38 others were spared because of the intervention of the Turkish Consul on Rhodes who managed, at some risk to his own safety, to convince the Germans to release any Turkish citizens (Turkey maintained neutrality in the war) and their families. My mother who had come to Rhodes from a Jewish community in Turkey had retained her Turkish citizenship.
} 
rived from children's early family experiences, can include unconscious redirected hostility stemming from frustration and repression. Allport (1954/1958) provided far-reaching expositions on various matters related to prejudice, but in keeping with The Authoritarian Personality, he maintained that prejudice is a problem of "personality formation and development" (Allport, 1954/1958, p. 39) characterized by weakness of ego, repression, anxiety, frustration, and aggression.

Approximately two decades later, psychological and developmental research focused increasingly on topics related to prejudice and discrimination - including implicit bias or unconscious prejudice, stereotyping, favorable and unfavorable attitudes toward in-groups and outgroups, the role of ethnic identity, judgments regarding race-based inclusion and exclusion in group activities, attitudes of tolerance and intolerance, stigmatization, and the role of competition.

\section{The Need for Psychology to Address Contemporary Forms of Eugenics}

What does the eugenics movement of the early twentieth century tell us about present times? While sterilization is no longer advocated or practiced, immigration restrictions surely remain. Trump's positions on immigration and on race, certainly reminiscent of the eugenics movement, are generally acknowledged to have helped him get elected president. As we have seen, he and his many followers regard Northern Europeans as worthy of entry into the country and those from Africa and countries like Haiti unworthy. As Bryan Stevenson suggests regarding the fiction that Black people are inferior to White people, deeply held conceptions of biologically determined racial differences in intelligence and a host of other characteristics (e.g., delinquency, crime, prostitution) persist. ${ }^{6}$ This aspect of thinking about biology, race, ethnicity, and nationality has not, in my view, been sufficiently studied in

\footnotetext{
6 In her book Caste: The Origins of Our Discontents (2020), Isabel Wilkerson maintains that rankings of people and groups are commonplace, featuring "an artificial construction, a fixed and embedded ranking of human value that sets the presumed supremacy of one group against the presumed inferiority of other groups on the basis of ancestry and often immutable traits, traits that would be neutral in the abstract but are ascribed life-anddeath meaning in a hierarchy favoring the dominant caste whose forebears designed it" (p. 17). By framing the issue in terms of castes, Wilkerson draws comparisons across time and geography: untouchables in India, Nazi Germany and Jews, the United States and African-Americans.

Within academic disciplines it is readily recognized that thinking presented in theoretical frameworks and methodologies can be incorrect or inadequate. This is reflected in the debates that occur within disciplines.
}

the field of psychology, neglected especially in developmental psychology. Clearly, biologists, psychologists, and other social scientists, over decades, thought about these issues, formulated theories, and gathered data that presumably support eugenics. But it is not only scholars who formulate systems of thinking about eugenics. I use the term thinking intentionally to encompass laypersons as well. In my work on theory and research about development in moral and other social domains, I invoke propositions by philosophers that "human beings are above all reasoning beings" (Nussbaum, 1999, p. 71) and that "Central to leading a human life ... are the responsibilities of choice and reasoning" (Sen, 2006, p. xiii). However, it is crucial to recognize that thinking is not always correct. ${ }^{7}$ Consider Jean Piaget's comments in this regard about erroneous thinking. Piaget (in Evans, 1973) explained that he was influenced to study thought and development in part because of his assessment of the shortcomings of intelligence testing. Working early in his career with Simon on standardizing the Binet-Simon intelligence test, Piaget noted (in Evans, 1973), "What really caught my interest was not a child's answers but the reasons behind his wrong answers. So I started looking at the reasons behind wrong answers" (pp. 32-33). An important aspect of his research program aimed at "discovering something about the reasoning process underlying their right, but especially their wrong answers" (in Evans, 1973, p. 119).

In order to better understand prejudice, discrimination, and segregation, it is important to also study the thinking that goes into current features of eugenics: in Bryan Stevenson's words, "that black people aren't as good as white people ... and are less evolved, less human, less capable, less worthy, less deserving than white people" (Chotiner, 2020); that people of some nationalities are less worthy of admission to the country than other nationalities; that intelligence is a unitary trait largely biologically determined; and that certain accepted moral prescriptions regarding welfare and equality do not apply to groups considered inferior.

The approach I have taken with a number of colleagues to the development of moral and social thinking is one avenue for such investigations. To state it briefly, many studies have demonstrated that by a young age children form judgments about morality, a domain involving concerns with welfare or harm, justice or fairness, and rights (Turiel, 2015). The dimensions of moral judgments are different from judgments about social conventions (involving customs and norms within social systems), which also differ from judgments in the personal domain (activities considered up to individual choice and discretion). 
The domains form distinctly different systems of thinking across ages (emotions are also part of all this; see Turiel, in press, and Turiel \& Killen, 2010), and developmental transformations occur within domains (Nucci et al., 2017).

Most relevant to the study of prejudice and discrimination are the broader categories societal and psychological (Turiel, 1983). Social conventional thinking is subsumed under the societal category and the personal is subsumed under the psychological. Conceptions about societal systems are likely involved in prejudice (especially with regard to immigration and segregation). However, most central to existing eugenic thinking is the category of the psychological, involving a variety of aspects of thinking about minds and actions. That is, people develop ways of thinking about the psychological make-up of individuals; research on theory of mind is one example of a well-studied aspect of the development of psychological thinking. Ideas about the biological (and environmental) sources of characteristics like intelligence are part of psychological thinking. Such ideas are implicated in conceptions about the nature of intelligence and group differences. Similarly, other conceptions of the social characteristics of groups of people, their relation to intelligence, and group divisions are all part of the realm of psychological thinking.

Moral judgments are also involved in eugenic thinking, but in the sense of a failure to apply moral prescrip- tions to everyone. As Martin Luther King Jr. put it, "So long as the lie was believed the brutality and criminality of conduct toward the Negro was easy for the conscience to bear" (King, 1968/1970). Relevant moral prescriptions involve equality and fairness. It is not necessarily the case that individuals who do not grant equality to certain groups lack understanding of equality. Rather, they may have concepts of equality but judge that equality should not be granted to those they consider "inferior." A good illustration of failure to apply moral concepts universally comes from philosophers' discussions of Aristotle's views on equality and personal freedoms. For instance, Sen (1997) noted that although ideas of freedom and equality were important in Aristotle's formulations, he excluded women and slaves from its purview. Another example is that the United States Declaration of Independence, with its assertions of equal rights ("We hold these truths to be self-evident that all men are created equal") did not include women or slaves. Thus, another important aspect of research should examine the ways moral judgments are or are not applied to racial, ethnic, and national groups.

I believe that a variety of approaches should continue to be pursued in research on prejudice and discrimination. But there is a pressing need to study the psychological thinking underlying eugenics, as well as its impact on individuals and societies.

\section{References}

Adorno, T. W., Frenkel-Brunswick, E., Levinson, D. J., \& Sanford, R. N. (1950). The authoritarian personality. Harper \& Row.

Allport, G. W. (1954/1958). The nature of prejudice. Addison-Wesley.

Chotiner, I. (2020, June 1). Bryan Stevenson on the frustrations behind the George Floyd protests. The New Yorker. https://www.newyorker.com/ news/q-and-a/bryan-stevenson-on-the-frustration-behind-the-george-floyd-protests

Cohen, A. (2016). Imbeciles: The Supreme Court, American eugenics and the sterilization of Carrie Buck. Penguin Books.

Evans, R. I. (1973). Jean Piaget: The man and his ideas. E. P. Dutton \& Co.

Frazier, I. (2019, August 26). Old hatred: Ninety years on, a white supremacist's nonsense isn't history yet. The New Yorker, 36-42.

Gould, S. J. (1981). The mismeasure of man. Norton.

Herrnstein, R. J. (1971). I.Q. Atlantic Monthly, 228(3), 43-64.

Herrnstein, R. J., \& Murray, C. (1994). The bell curve: Intelligence and class structure in American life. Vintage.

Jensen, A. (1969). How much can we boost IQ and scholastic achievement. Harvard Educational Review, 39(1), 1-123. https://doi.org/10.17763/ haer.39.1.13u15956627424k7
King, M. L., Jr. (1968/1970). Honoring Dr. Du Bois. Special Collections and University Archives, University of Massachusetts Amherst Libraries. https://credo.library.umass.edu/view/full/ mums312-b287-i008

Leonard, T. C. (2016). Illiberal reformers: Race, eugenics \& American economics in the progressive era. Princeton University Press. https://doi. org/10.2307/j.ctvc77cqn

Nucci, L., Turiel, E., \& Roded, A. D. (2017). Continuities and discontinuities in the development of moral judgments. Human Development, 60(6), 279-341. https://doi.org/10.1159/ 000484067

Nussbaum, M. C. (1999). Sex and social justice. Oxford University Press.

Sen, A. (1997, July $14 \& 21$ ). Human rights and Asian values. The New Republic, 33-39.

Sen, A. (2006). Identity and violence: The illusion of destiny. Norton.

Supreme Court of United States (1927). Buck v. Bell. 274 U.S. 200 (1927). https://scholar. google.com/scholar_case? q=Buck+v.+Bell. +2 $74+$ U.S. $+200+(1927) . \& h l=e n \& a s \_s d t=806 \& c$ ase $=1700304772805702914 \&$ scilh $=0$

Trump, D. J. [@realDonaldTrump]. (2020, August 12). The "suburban housewife" will be voting for me. They want safety \& are thrilled that I ended the long running [Tweet]. Twitter. https://twitter.com/realDonaldTrump/status/ 1293517514798960640

Turiel, E. (1983). Domains and categories in socialcognitive development. In W. Overton (Ed.), The relationship between social and cognitive development (pp. 53-89). Erlbaum Associates.

Turiel, E. (2015). Moral development. In W. F. Overton \& P. C. Molenaar (Eds.), Handbook of child psychology and developmental science, Vol. 1: Theory \& method (7th ed., pp. 484-522). John Wiley \& Sons. https://doi.org/10.1002/ 9781118963418.childpsy113

Turiel, E. (in press). The development of moral judgments, emotions, and sentiments. In D. Dukes, A. Samson, \& E. Walle (Eds.), Oxford handbook of emotional development. Oxford University Press.

Turiel, E., \& Killen, M. (2010). Taking emotions seriously: The role of emotions in moral development. In W. Arsenio \& E. Lemerise (Eds.), Emotions, aggression, and morality in children: Bridging development and psychopathology (pp. 33-52). American Psychological Association. https://doi.org/10.1037/12129002

Wilkerson, I. (2020). Caste: The origins of our discontents. Random House. 